\title{
Triterpenoid constituents and Their Anti-cancer activity from stems and branches of Sambucus williamsii var. coreana Nakai (Caprifoliaceae)
}

\author{
Hyun-Hee KIM ${ }^{1 \ddagger}$, Songmi LEE ${ }^{2 \ddagger}$, Seo-Hee Kim¹${ }^{1}$, Soon-Ho YIM ${ }^{1 \star}$
}

\begin{abstract}
This study aims at characterization of the anti-cancer active compounds separated from stems and branches of Sambucus williamsii var. coreana Nakai (Caprifoliaceae). Bioactivity-guided fractionation of ethanol extracts from the S. williamsii was isolated of three triterpenoid compounds. S. williamsii fractions showed superior growth inhibitory activity against three cancer cells (HCT116, A549 and MDA-MB231). Active fraction was isolated and analyzed and led to the identification of three active triterpenoid compounds using HPLC, NMR, and LC-MS spectrometer, their structures were established as betulinic acid (1), oleanolic acid (2) and ursolic acid (3). The results of this study performed with S. williamsii will be helpful to develop new and efficient anti-cancer agents. Also, this research was supported the previous separations and isolations studies on active ingredients of S. williamsii.
\end{abstract}

Keywords: Sambucus williamsii var. coreana Nakai (Caprifoliaceae); anti-cancer; Triterpenoid; betulinic acid; oleanolic acid; ursolic acid.

Practical Application: Anti-cancer drug development for natural lead compounds using the S. williamsii

\section{Introduction}

Cancer is one of the health problems leading to major deaths worldwide, incidence rate is gradually decreased in domestic due to new diagnosis and treatment methods, but cancer mortality rate is increased, and cancer is still one of the major causes of death in developed countries (National Cancer Center, 2017). It is well established that cancer is a progressive disease, occurring in a series of well-defined steps, typically arising as a consequence of activating mutations (oncogenes) or deactivating mutations (tumor suppressor genes) in proliferating cells (Coussens \& Werb, 2001). Increasing knowledge of the molecular mechanisms underlying cancer progression has led to the development of a vast number of anticancer drugs. However, the use of chemically synthesized drugs has not significantly improved the overall survival rate over the past few decades (Choudhari et al., 2020). In addition to the anti-cancer effects against cancer cells, anticancer drugs show toxic effects against normal cells, and thus exhibited adverse effects (Fulda, 2008).

Medicinal Plants have been demonstrated relevant to be a very viable source of clinically anti-cancer compounds (Mongelli et al., 2000). Natural products have been used for combating human diseases for thousands of years, since they exhibit a wide range of biological properties that can be exploited for medical application (Newman et al., 2003). Since natural materials are also less toxic, many researchers are studying structure identification and the function of natural substances which have little side effects on the body (Fulda, 2008; Mongelli et al., 2000). Also, natural products contain a variety of substances with various functionalities such as antioxidant, anti-cancer, anti-inflammatory, anti-hypertensive, antiviral effects. In fact, most of the anti-cancer and anti-infectious agents are based on natural products origin. In addition, the anti-cancer activity of natural products has been linked their ability to trigger cell death pathways including apoptosis in cancer cells (Fulda, 2008).

Sambucus williamsii var. coreana Nakai (Caprifoliaceae) has acylindrical shape with stems and branches, and its outer surface is greenish brown with a diameter of $5 \sim 12 \mathrm{~mm}$ (Tili et al., 2011). These plants are mainly located along the slopes of mountains, stream sides and roads, and have high environmental adaptability. It grows extensively throughout Korea, Japan and northern China and consists of several active ingredients such as flavonoids, tannins, caffeic acid derivatives, steroid substances and other isolated substances. S. williamsii is not widely used by humans, however the animals use its fruit as food, and it has been used as a remedy for the left upper part of the muscles from ancient times in our country folk remedies. In addition, the leaves of the plant are used against various types of inflammatory disorders in Turkish folk medicine (Tili et al., 2011; Crusz \& Balkwill, 2015; Balkan et al., 2017). Previous experimental studies have reported several pharmacological effects such as antimicrobial, anti-giardial, wound healing, anti-helicobacter pylori, anti-ulcer and radical scavenging activity to except anti-cancer activity of S. williamsii (Mantovani et al., 2008; Candido \& Hagemann, 2013; Balkwill et al., 2005).

Therefore, in present work, we report isolation and identification of three triterpenoids (1-3) from S. williamsii stems and branches

*Corresponding author: virshyim@gmail.com 
through bioactivity-guided extraction and fractionation. Their structures were determined by spectroscopic method and LC/ MS. Moreover, this paper first focused on anti-cancer inhibition effect on HCT116 (Human colorectal carcinoma cell line), A549 (Human lung carcinoma cell line) and MDA-MB231 (Human breast carcinoma cell line).

\section{Materials and methods}

\subsection{Instrument and reagents}

Nuclear Magnetic Resonance (NMR) was performed on a Varian unity Inova NMR spectrometer (Varian, Palo Alto, CA, USA) ${ }^{1} \mathrm{H}: 600 \mathrm{MHz}$ and ${ }^{13} \mathrm{C}: 151 \mathrm{MHz}$. HR-ESI-MS data were acquired using a Bruker maXis $4 \mathrm{G}$ mass spectrometer (Bruker, Bremen, Germany). Separation was performed on Semi-preparative HPLC was carried out on a Waters"' (Milford, MA, USA) 600E multi solvent delivery system connected with a DECASSITTM 6342 degasser, using Atlantis Prep T3 OBD $(5 \mu \mathrm{m}, 19 \times 250 \mathrm{~mm})$ columns (Milford, MA, USA). Analytical HPLC-DAD was performed on an Agilent Technologies 1100 series (Santa Clara, CA, USA), which consists of a degasser, a binary mixing pump and a column, using YMC HPLC column (ODS S-5 $\mu \mathrm{m} 4.6 \times 150 \mathrm{~mm}$; Yamamura Chemical Laboratories, Kyoto, Japan). The solvent used for the extraction and separation of the stems and branches of $S$. williamsii was ethanol, methanol and acetonitrile as HPLC grade reagent from Burdick \& Jackson (Muskegon, MI, USA). The Dulbccos's Modified Eagle Medium (DMEM) and Fetal bovine serum (FBS) for cell culture were purchased from Hyclone Laboratories, Inc (Hyclone Laboratories, Logan, UT). Penicillin/Streptomycin (P/S) and Trypsin-EDTA (TE) were purchased from Lonza (Lonza, Basel Swiss, USA).

\subsection{Plant materials}

S. williamsii var. coreana Nakai (Caprifoliaceae) stems and branches were purchased from Dong Kwang Han Materials Co. Ltd., which is the origin of Jecheon in Chungbuk, Korea.

\subsection{Extraction of S. williamsii}

The dried stems and branches of S. williamsii $(0.3 \mathrm{~kg})$ were extracted with $95 \%$ Ethanol at $70^{\circ} \mathrm{C}$ for 1 hour ( 3 times) using a ultrasonicator and combined ethanolic extracts were evaporated to dryness under reduced pressure to yield $14.2 \mathrm{~g}$ S. williamsii ethanolic extracts (4.7\%, extraction yield).

\subsection{Fractionation and isolation}

The stems and branches of S. williamsii ethanolic extracts were dissolved in distilled water and fractionated by adsorption on Diaion HP-20 column resin $(2.8 \times 20 \mathrm{~cm}$, wet volume $50 \mathrm{~mL}$; Mitsubishi Chemical Corporation, Tokyo, Japan) in open column chromatography. Subsequently, sub-fractions were generated by mixing DW: Ethanol to increasing the amount of ethanol [70: $30 \rightarrow 40: 60 \rightarrow 20: 80 \rightarrow 0: 100, v / v, 1,000 \mathrm{~mL}, 3$ times] using a sequential gradient system. Sub-fractions were then evaporated to dryness under reduced pressure. Then the sub-fraction was subjected to the column chromatography on YMC reverse-phase
(RP) ODS (YMC, Kyoto, Japan) eluted by 100\% Acetonitrile with the flow rate of $0.375 \mathrm{~mL} / \mathrm{min}$ at $205 \mathrm{~nm}$ and run time of 40 min solvent systems using HPLC-DAD method.

The structures of compounds $\mathbf{1}$ to $\mathbf{3}$ were elucidated by using ${ }^{1} \mathrm{H}(600 \mathrm{MHz})$ and ${ }^{13} \mathrm{C}(151 \mathrm{MHz})$ nuclear magnetic resonance (NMR) and Liquid chromatography-mass spectrometry (LC/MS) techniques.

Compound 1 White amorphous powder; ESI-MS $m / z$ : $455.2000[\mathrm{M}-\mathrm{H}]^{-}$(calced. for $\mathrm{C}_{30} \mathrm{H}_{48} \mathrm{O}_{3}$ ); ${ }^{1} \mathrm{H}$ NMR ( $\mathrm{CD}_{3} \mathrm{OD}$, $600 \mathrm{MHz}) \delta_{\mathrm{H}}(\mathrm{ppm}): 4.71(1 \mathrm{H}, \mathrm{d}, J=2.3 \mathrm{~Hz}, \mathrm{H}-29 \beta), 4.59(1 \mathrm{H}$, dd, $J=2.3,1.4 \mathrm{~Hz}, \mathrm{H}-29 \alpha), 3.13$ (1H, dd, $J=11.6,4.7 \mathrm{~Hz}, \mathrm{H}-3)$, 1.70 (3H, s, H-30), 1.01 (3H, s, H-23), 0.97 (3H, s, H-24), 0.95 (3H, s, H-27), 0.86 (3H, s, H-26), $0.76(3 \mathrm{H}, \mathrm{s}, \mathrm{H}-25)$. The ${ }^{13} \mathrm{C}$ NMR data of the compound $\mathbf{1}$ is shown in Table 1.

Compound 2 White powder; ESI-MS m/z: 455.2000 [M-H] (calced. for $\left.\mathrm{C}_{30} \mathrm{H}_{48} \mathrm{O}_{3}\right) ;{ }^{1} \mathrm{H}$ NMR $\left(\mathrm{CD}_{3} \mathrm{OD}, 600 \mathrm{MHz}\right) \delta_{\mathrm{H}}(\mathrm{ppm})$ : $5.21(1 \mathrm{H}, \mathrm{t}, J=3.6 \mathrm{~Hz}, \mathrm{H}-12), 3.14(1 \mathrm{H}, \mathrm{dd}, J=11.7,4.5 \mathrm{~Hz}, \mathrm{H}-3)$, $2.91(1 \mathrm{H}, \mathrm{dd}, J=14.7,3.9 \mathrm{~Hz}, \mathrm{H}-18), 1.13$ (3H, s, H-27), 0.97 (3H, s, H-25), 0.95 (3H, s, H-24), 0.94 (6H, d, J=3.0 Hz, H-29, 30), 0.88 (3H, s, H-26), 0.77 (3H, s, H-23). The ${ }^{13} \mathrm{C}$ NMR data of the compound 2 is shown in Table 1.

Table 1. ${ }^{13} \mathrm{C}$ NMR spectroscopic data $\left(600 \mathrm{MHz}\right.$ in $\left.\mathrm{CD}_{3} \mathrm{OD}\right)$ for compound 1-3.

\begin{tabular}{|c|c|c|c|}
\hline Position & 1 & 2 & 3 \\
\hline 1 & 40.2 & 38.4 & 38.8 \\
\hline 2 & 28.2 & 28.0 & 28.1 \\
\hline 3 & 79.8 & 80.0 & 80.0 \\
\hline 4 & 40.1 & 40.0 & 40.7 \\
\hline 5 & 57.7 & 57.0 & 60.0 \\
\hline 6 & 19.6 & 19.7 & 18.0 \\
\hline 7 & 35.7 & 34.1 & 31.8 \\
\hline 8 & 42.1 & 40.0 & 40.9 \\
\hline 9 & 52.1 & 43.6 & 50.4 \\
\hline 10 & 38.3 & 36.7 & 38.3 \\
\hline 11 & 22.2 & 24.5 & 22.0 \\
\hline 12 & 27.0 & 122.6 & 125.9 \\
\hline 13 & 39.8 & 146.8 & 141.9 \\
\hline 14 & 43.7 & 40.7 & 43.5 \\
\hline 15 & 31.0 & 28.9 & 28.9 \\
\hline 16 & 33.5 & 24.7 & 24.2 \\
\hline 17 & 57.0 & 49.7 & \\
\hline 18 & 48.7 & 40.5 & 55.2 \\
\hline 19 & 50.6 & 48.3 & 40.3 \\
\hline 20 & 152.2 & 32.0 & 40.2 \\
\hline 21 & 31.9 & 35.7 & 29.8 \\
\hline 22 & 38.5 & 34.3 & 34.7 \\
\hline 23 & 28.8 & 29.4 & 28.3 \\
\hline 24 & 16.3 & 16.5 & 14.6 \\
\hline 25 & 16.9 & 16.0 & 14.6 \\
\hline 26 & 16.8 & 18.3 & 16.5 \\
\hline 27 & 15.2 & 26.6 & 23.9 \\
\hline 28 & 180.3 & 170.5 & 179.8 \\
\hline 29 & 110.1 & 34.5 & 16.2 \\
\hline 30 & 19.7 & 24.7 & 19.7 \\
\hline
\end{tabular}


Compound 3 White powder; ESI-MS $m / z: 455.1000$ [M-H] (calced. for $\left.\mathrm{C}_{30} \mathrm{H}_{48} \mathrm{O}_{3}\right)$; ${ }^{1} \mathrm{H} \mathrm{NMR}\left(\mathrm{CD}_{3} \mathrm{OD}, 600 \mathrm{MHz}\right) \delta_{\mathrm{H}}(\mathrm{ppm})$ : $5.20(1 \mathrm{H}, \mathrm{t}, J=3.6 \mathrm{~Hz}, \mathrm{H}-12), 3.15(1 \mathrm{H}, \mathrm{dd}, J=11.4,4.2 \mathrm{~Hz}, \mathrm{H}-3)$, 2.27 (1H, d, J=11.3 Hz, H-18), 1.09 (3H, s, H-27), 0.97 (3H, s, H-23), 0.96 (3H, s, H-26), 0.91 (3H, s, H-24), 0.90 (3H, d, J=7.2 $\mathrm{Hz}, \mathrm{H}-29), 0.87$ (3H, d, J=6.0 Hz, H-30), 0.78 (3H, s, H-25). The ${ }^{13} \mathrm{C}$ NMR data of the compound 3 is shown in Table 1.

\subsection{Measurement of Anticancer Activity against carcinoma Cell Lines}

The inhibition of the cellular growth was estimated using MTT (3-(4,5-dimethyl-2-thiazolyl)-2,5-diphenyl-2H-tetrazolium bromide) assay as described by Mosmann with a slight modification (Mosmann, 1983). The cancer cell lines of HCT116 (colorectal carcinoma cell), A549 (lung carcinoma cell) and MDA-MB231 (breast carcinoma cell) were seeded into 96 well plates in a total volume of $100 \mu \mathrm{L}$ per well $\left(1 \times 10^{4}\right.$ cells/well for HCT116, A549 and MDA-MB231 cells) and incubated at $37^{\circ} \mathrm{C}$ in a humidifed atmosphere containing $5 \% \mathrm{CO}_{2}$ for 24 hours. The medium was replaced with fresh medium with various concentrations of samples for 48 hours. After the exposure time, $100 \mu \mathrm{L}$ of MTT was added to the wells and the cells incubated for another 3 hours. The formazan formed was dissolved in dimethyl sulfoxide, and the absorbance was measured at $570 \mathrm{~nm}$ by microplate reader (Mecasys, Optizen 2120 UV, Daejeon, Korea).

\subsection{Statistical analysis}

All the values presented in the study were expressed as mean \pm standard deviation. The statistical difference between the mean ulcer index of the treated group and that of the control was calculated by using one-way analysis of variance (ANOVA) and Duncan's multiple range test. All statistical tests were performed by using the software Statistical Package for the Social Sciences (SPSS).

\section{Result}

\subsection{Isolation and identification of active compound}

Three compounds were isolated constituents stems and branches of S. williamsii var. coreana Nakai (Caprifoliaceae). The chemical structures of compounds 1, 2 and 3 were analyzed and determined using on-line structural information which were obtained by NMR spectroscopic methods and LC/MS.

Compound 1 was a white needle-shaped crystals and the ESI-MS spectrum showed a molecular ion peak at $\mathrm{m} / z 455$ $[\mathrm{M}-\mathrm{H}]-{ }^{1} \mathrm{H}-\mathrm{NMR}$ spectrum showed olefinic proton signals due to exo-methylene at $\delta 4.71(1 \mathrm{H}, \mathrm{d}, J=2.3 \mathrm{~Hz}, \mathrm{H}-29 \beta)$ and 4.59 $(1 \mathrm{H}, \mathrm{dd}, J=2.3,1.4 \mathrm{~Hz}, \mathrm{H}-29 \alpha)$. Hydroxylated methine proton signal was observed at $\delta 3.13(1 \mathrm{H}, \mathrm{dd}, J=11.6,4.7 \mathrm{~Hz}, \mathrm{H}-3)$. Also, $\delta 1.70$ (3H, s, H-30), 1.01 (3H, s, H-23), 0.97 (3H, s, H-24), $0.95(3 \mathrm{H}, \mathrm{s}, \mathrm{H}-27), 0.86(3 \mathrm{H}, \mathrm{s}, \mathrm{H}-26)$ and $0.76(3 \mathrm{H}, \mathrm{s}, \mathrm{H}-25)$ of six angular methyl groups was shown as singlet signals. In the ${ }^{13} \mathrm{C}$-NMR spectrum the signal of the carboxyl group was observed at $\delta 180.3$ (C-28) and olefinic quaternary carbon due to exo-methylene at $\delta 152.2$ (C-20). Also, many methine and methyl carbon signals were observed. The structure of compound
1 was determined to be (3ß)-3-hydroxy-lup-20(29)-en-28-oic acid (Betulinic acid) by comparison with their spectroscopic means with those previously reported in the literatures (Figure 1) (Igoli \& Gray, 2008; Salah \& Bakibaev, 2017; Kim et al., 2002).

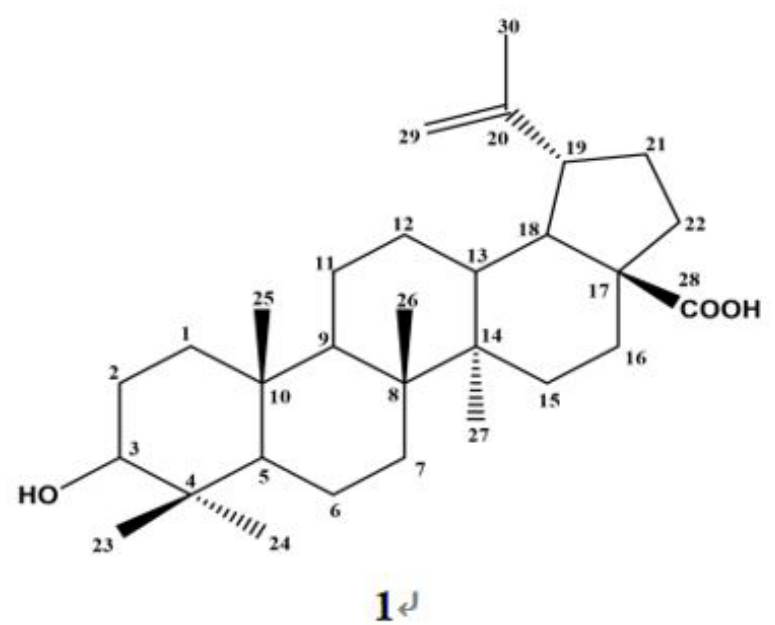

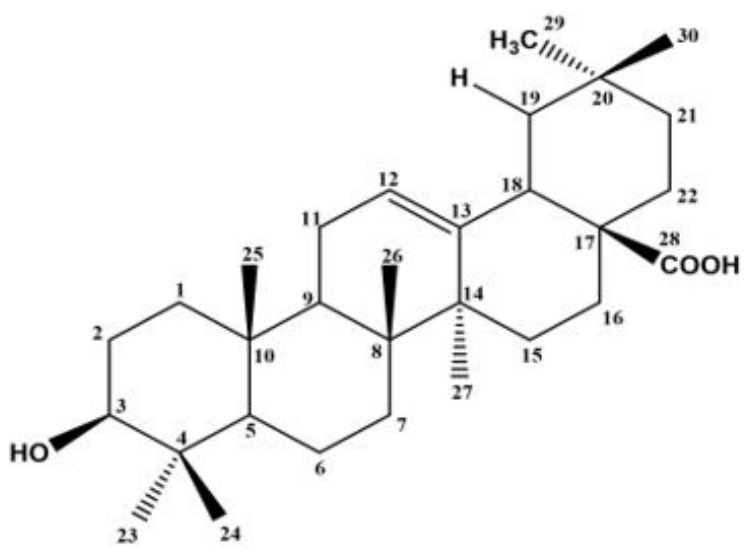

2

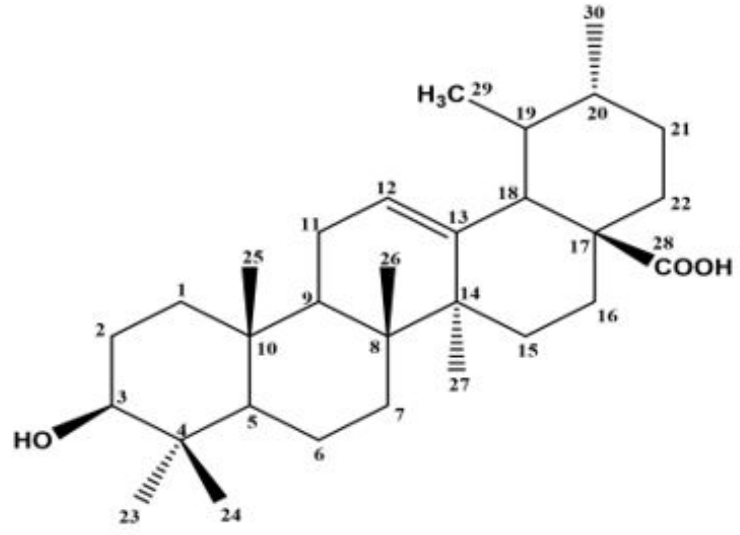

3

Figure 1. Chemical structures of isolated compounds 1-3 (Compound 1: betulinic acid, Compound 2: oleanolic acid, Compound 3: ursolic acid). 
Compound 2 was a white crystal and the ESI-MS spectrum showed a molecular ion peak at $m / z 455[\mathrm{M}-\mathrm{H}] \cdot{ }^{-1} \mathrm{H}-\mathrm{NMR}$ spectrum showed an olefine methine proton signal at $\delta 5.21$ $(1 \mathrm{H}, \mathrm{t}, J=3.6 \mathrm{~Hz}, \mathrm{H}-12)$. Oxygenated methine proton signal at $\delta 3.14(1 \mathrm{H}, \mathrm{dd}, J=11.7,4.5 \mathrm{~Hz}, \mathrm{H}-3)$ was observed in the oxygen substituted region. Numerous methylene and methine proton signals were observed in the $\delta 2.91(1 \mathrm{H}, \mathrm{dd}, J=14.7,3.9$ $\mathrm{Hz}, \mathrm{H}-18)$ region. Also, singlet signals of seven angular methyl groups were showed in the $\delta 1.13(3 \mathrm{H}, \mathrm{s}, \mathrm{H}-27), 0.97(3 \mathrm{H}, \mathrm{s}$, $\mathrm{H}-25), 0.95$ (3H, s, H-24), 0.94 (6H, H-29, 30) 0.88 (3H, s, H-26) and $0.77(3 \mathrm{H}, \mathrm{s}, \mathrm{H}-23)$. In the ${ }^{13} \mathrm{C}-\mathrm{NMR}$ spectrum the signals such as the carboxyl carbon signal at $\delta 170.5$ (C-28), olefinic quaternary carbon signal at $\delta 146.8(\mathrm{C}-13)$ and olefine methine carbon signal at $\delta 122.6(\mathrm{C}-12)$ were observed. Oxygenated methine carbon signal at $\delta 80.0(\mathrm{C}-3)$ was observed in the oxygen replacement zone. Based on these data, Compound 2 was identified as 3 $\beta$-hydroxyolean-12-en-28-oic acid (Oleanolic acid) (Figure 1) (Igoli \& Gray, 2008; Kim et al., 2013).

Compound 3 was a white crystal and the ESI-MS spectrum showed a molecular ion peak at $m / z 455[\mathrm{M}-\mathrm{H}] \cdot .{ }^{1} \mathrm{H}-\mathrm{NMR}$ spectrum showed an olefine methine proton signal at $\delta 5.20$ $(1 \mathrm{H}, \mathrm{t}, J=3.6 \mathrm{~Hz}, \mathrm{H}-12)$. Oxygenated methine proton signal at $\delta 3.15(1 \mathrm{H}, \mathrm{dd}, J=11.4,4.2 \mathrm{~Hz}, \mathrm{H}-3)$ was observed. Doublet methyl proton signals at $\delta 0.90(3 \mathrm{H}, \mathrm{d}, J=7.2 \mathrm{~Hz} \mathrm{H}-29)$ and 0.87 $(3 \mathrm{H}, \mathrm{d}, J=6.0 \mathrm{~Hz} \mathrm{H}-30)$ were observed. Also, singlet signals of five angular methyl groups were shown at $\delta 1.09(3 \mathrm{H}, \mathrm{s}, \mathrm{H}-27)$, 0.97 (3H, s, H-23), 0.96 (3H, s, H-26), 0.91 (3H, s, H-24) and $0.78(3 \mathrm{H}, \mathrm{s}, \mathrm{H}-25)$. In the ${ }^{13} \mathrm{C}-\mathrm{NMR}$ spectrum signals such as the carboxyl carbon signal at $\delta 179.8$ (C-28), olefinic quaternary carbon signal at $\delta 141.9(\mathrm{C}-13)$ and olefine methine carbon signal at $\delta 125.9(\mathrm{C}-12)$ were showed. The oxygenated methine carbon signal at $\delta 80.0$ (C-3) was also observed. Also, many methyl carbon, methylene carbon, methine carbon and quaternary carbon signals were identified. Based on these data, Compound 3 was identified as 3 $\beta$-hydroxyurs-12-en-28-oic acid (Ursolic acid) (Figure 1) (Luna-Vázquez et al., 2016).

\subsection{Cancer cell growth inhibitory effect}

We investigated the cancer cell growth inhibitory effects of $S$. williamsii ethanolic extracts, the compounds 1-3 in three different human carcinoma cell lines (human lung carcinoma A549, human breast carcinoma MDA-MB231 and human colorectal carcinoma HCT116) using the MTT assay (Table 2, Figure 2). S. williamsii ethanolic extracts showed relatively high growth inhibitory activity with the $\mathrm{IC}_{50}$ value. Among the fractions sFR.1sFR.9, sub-fraction 8 (sFR.8) was exhibited highest inhibitory effects against carcinoma lines in a concentration dependent manner with $\mathrm{IC}_{50}$ values of 29,17 and $35 \mu \mathrm{g} / \mathrm{mL}$ (Table 2). To test whether these three isolated compounds were contributed to the anti-cancer activity of sub-fraction 8, the MTT assay on three different human cancer cell lines were examined and compared. Compounds 1-3 were isolated from the sFR.8 of the $S$. williamsii ethanolic extracts (Figure 1). And Compound 3 showed the highest growth inhibitory activity values of $70 \pm$ $1.42,84 \pm 1.62$, and $72 \pm 0.31 \%$ at a concentration of $20 \mu \mathrm{g} / \mathrm{mL}$ in A549, MDA-MB231 and HCT116 cells, respectively. These results indicated that the pure three compound isolated from the sub-fraction 8 of S. williamsii has significant anti-cancer effects against cancer cells (Figure 2).

\section{Discussion}

S. williamsii var. coreana Nakai (Caprifoliaceae) has been traditionally used in the treatment of bone fractures, analgesic, gastrointestinal disorders and antipyretic. Anti-inflammatory, anti-ulcerogenic and wound healing activities of S. williamsii leaves were previously investigated by several research groups and isolated a number of active components (Balkan et al., 2017; Yesilada et al., 2014; Ahmadiani et al., 1998; Yeşilada et al., 1997). However, the anti-cancer effects and cytotoxic components of the plant have not been extensively studied (Tili et al., 2011; Crusz and Balkwill, 2015; Mantovani et al., 2008; Candido \& Hagemann, 2013; Macarthur et al., 2004; Zur Hausen, 2007). Thus, We investigated the cancer cell growth inhibitory effects of S. williamsii ethanolic extracts, the compounds 1-3 in three different human carcinoma cell lines (human lung carcinoma A549, human breast carcinoma MDA-MB231 and human colorectal carcinoma HCT116) using the MTT assay (Table 2, Figure 2). To test whether these three isolated compounds were contributed to the anti-cancer activity of sub-fraction 8 , the MTT assay on three different human cancer cell lines were examined and compared. And compounds $\mathbf{1}$ and $\mathbf{3}$ showed very high growth inhibitory activity in cancer cell lines (Figure 2).

Table 2. Growth inhibitory activities of S. williamsii extracts and Sub-fractions on Carcinoma cell lines.

\begin{tabular}{lcccc}
\hline \multicolumn{1}{c}{ Sample } & & \multicolumn{2}{c}{ IC $_{\text {50 }}{ }^{1)}(\boldsymbol{\mu g} / \mathbf{m L})$} \\
\cline { 3 - 5 } & & A549 & MDA-MB231 & HCT116 \\
\hline S. williamsii ethanolic extracts & & 142.88 & 137.65 & 279.18 \\
Sub-fractions & sFR.1 & $>300$ & $>300$ & 262.39 \\
& sFR.2 & $>300$ & $>300$ & $>300$ \\
& sFR.3 & $>300$ & $>300$ & 157.86 \\
& sFR.4 & $>300$ & 2300 & 38.78 \\
& sFR.5 & 168.69 & 219.08 & 173.25 \\
& sFR.6 & $>300$ & 213.45 & 36.03 \\
& sFR.7 & 93.98 & 17.47 & 35.24 \\
& sFR.8 & 29.81 & 43.83 & 37.07 \\
\hline
\end{tabular}

\footnotetext{
${ }^{1)} \mathrm{IC}_{50}$ means is the concentration of sample required for growth inhibition of $50 \%$.
} 


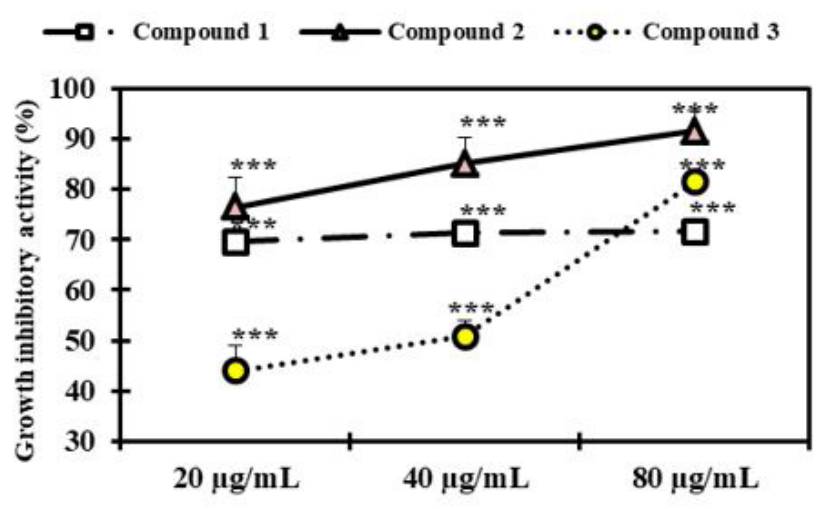

(A) $\mathbf{A 5 4 9}$

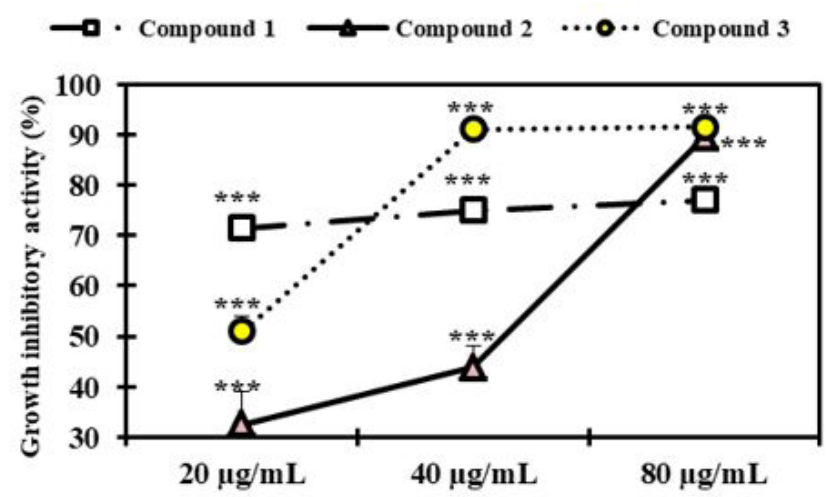

(B) HCT116

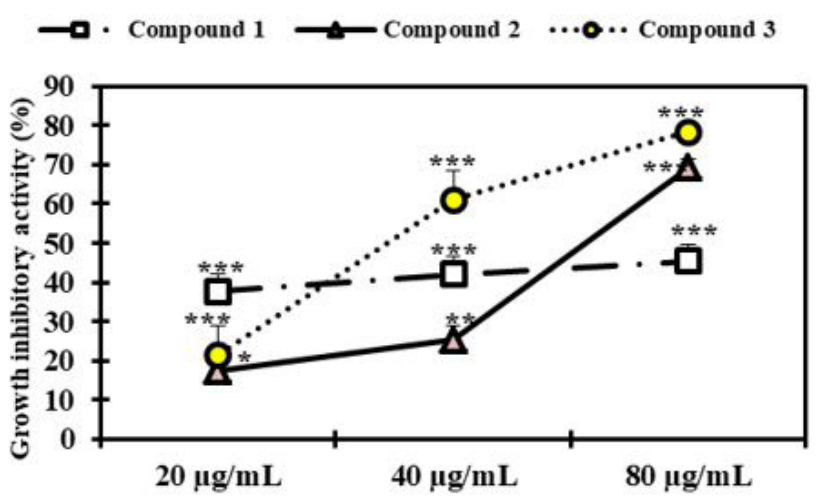

(C) MDA-MB231

Figure 2. The effects of the compounds 1-3 isolated from 8 subfraction of $S$. williamsii on the growth inhibitory in A549, HCT116 and MDA-MB231 cell (Compound 1: betulinic acid, Compound 2: oleanolic acid, Compound 3: ursolic acid). The data expressed as the mean \pm standard deviation $(n=3) .{ }^{*}$ Compare with the control: ${ }^{*} \mathrm{p}<0.05$, ${ }^{* *} \mathrm{p}<0.01,{ }^{* * *} \mathrm{p}<0.001$.

The triterpenoids are the most representative group of phytochemicals; they comprise more than 20,000 recognized compounds and are biosynthesized in plants through squalene cyclization (Jesus et al., 2015). Triterpenes is highly associated with their broad range of pharmacological effects such as antiinflammatory, hepatoprotective, anti-cancer. In addition, some studies have already demonstrated that the isolated compounds exhibit antiallergic, antiangiogenic and anti-cancer potential (Igoli and Gray, 2008; Salah \& Bakibaev, 2017; Kim et al., 2013). Compound $\mathbf{1}$ is betulinic acid, which exhibits antitumor activity through activation of the mitochondrial pathway of apoptosis in cancer cells. It is a promising experimental anti-cancer agent for the treatment of human cancer with relatively selective cytotoxicity. Compound $\mathbf{2}$ is oleanolic acid and has several interesting pharmacological activities, such as antioxidant, anti-inflammatory, anti-cancer and hepatoprotective effects. Except the already proven pharmacological effects of ursolic acid (compound 3) in this study, other reports have shown that ursolic acid exhibit antitumor, antibacterial and antiparasitic properties (Fulda, 2008; Luna-Vázquez et al., 2016; Jesus et al., 2015).

Consideration of the complex development of cancer, formulation of novel anti-cancer pharmaceuticals is difficult. Compounds with cytotoxic effects are selected as first-ranked candidate to discover anti-cancer drugs and mitochondrial targeted agents such as betulinic acid can open new perspectives to overcome some forms of drug resistance (Mongelli et al., 2000; Suffness, 1990; Saravi et al., 2013). It has been demonstrated that the triterpenoid compounds betulinic acid (1), oleanolic acid (2) and ursolic acid (3) isolated from stems and branches of S. williamsii have anti-cancer effects. This study will be helpful to develop new and efficient anti-cancer agents (Figure 2).

This study aims at characterization of the anti-cancer active compounds separated from stems and branches of S. williamsii var. coreana Nakai (Caprifoliaceae). Isolated compounds were identified as betulinic acid (1), oleanolic acid (2) and ursolic acid (3) by spectroscopic analyses and comparison with published data, and the triterpenoid constituents showed anti-cancer activity in various cancer cells. Most of the experimental evidence led to the conclusion that $S$. williamsii was a potential drug for the prevention and treatment of cancer. In addition, this study strongly supports the previous separation studies on active ingredients of $S$. williamsii. The results of this study performed with $S$. williamsii will be helpful to develop new and efficient anti-cancer agents.

\section{Ethical approval}

This article dose not contain any studies with human participants or animals performed by any of the authors.

\section{Conflict of interest}

The authors declare that they have no conflict of interest.

\section{Funding}

The study did not receive any funds.

\section{References}

Ahmadiani, A., Fereidoni, M., Semnanian, S., Kamalinejad, M., \& Saremi, S. (1998). Antinociceptive and anti-inflammatory effects of Sambucus ebulus rhizome extract in rats. Journal of Ethnopharmacology, 61(3), 229-235. http://dx.doi.org/10.1016/S0378-8741(98)00043-9. PMid:9705014. 
Balkan, İ. A., İlter Akülke, A. Z., Bağatur, Y., Telci, D., Gören, A. C., Kırmızıbekmez, H., \& Yesilada, E. (2017). Sambulin A and B, non-glycosidic iridoids from Sambucus ebulus, exert significant in vitro anti-inflammatory activity in LPS-induced RAW 264.7 macrophages via inhibition of MAPKs's phosphorylation. Journal of Ethnopharmacology, 206, 347-352. http://dx.doi.org/10.1016/j. jep.2017.06.002. PMid:28606808.

Balkwill, F., Charles, K. A., \& Mantovani, A. (2005). Smoldering and polarized inflammation in the initiation and promotion of malignant disease. Cancer Cell, 7(3), 211-217. http://dx.doi.org/10.1016/j. ccr.2005.02.013. PMid:15766659.

Candido, J., \& Hagemann, T. (2013). Cancer-related inflammation. Journal of Clinical Immunology, 33(1, Suppl. 1), 79-84. http://dx.doi. org/10.1007/s10875-012-9847-0. PMid:23225204.

Choudhari, A. S., Mandave, P. C., Deshpande, M., Ranjekar, P., \& Prakash, O. (2020). Phytochemicals in cancer treatment: from preclinical studies to clinical practice. Frontiers in Pharmacology, 10, 1614. http://dx.doi.org/10.3389/fphar.2019.01614. PMid:32116665.

Coussens, L. M., \& Werb, Z. (2001). Inflammatory cells and cancer: think different! The Journal of Experimental Medicine, 193(6), F23-F26. http://dx.doi.org/10.1084/jem.193.6.F23. PMid:11257144.

Crusz, S. M., \& Balkwill, F. R. (2015). Inflammation and cancer: advances and new agents. Nature Reviews. Clinical Oncology, 12(10), 584-596. http://dx.doi.org/10.1038/nrclinonc.2015.105. PMid:26122183.

Fulda, S. (2008). Betulinic acid for cancer treatment and prevention. International Journal of Molecular Sciences, 9(6), 1096-1107. http:// dx.doi.org/10.3390/ijms9061096. PMid:19325847.

Igoli, O. J., \& Gray, I. A. (2008). Friedelanone and other triterpenoids from Hymenocardia acida. International Journal of Physical Sciences, 3(6), 156-158.

Jesus, J. A., Lago, J. H. G., Laurenti, M. D., Yamamoto, E. S., \& Passero, L. F. D. (2015). Antimicrobial activity of oleanolic and ursolic acids: an update. Evidence-Based Complementary and Alternative Medicine, 2015, 620472. http://dx.doi.org/10.1155/2015/620472. PMid:25793002.

Kim, D. K., Nam, I. Y., Kim, J. W., Shin, T. Y., \& Lim, J. P. (2002). Pentacyclic triterpenoids fromllex macropoda. Archives of Pharmacal Research, 25(5), 617-620. http://dx.doi.org/10.1007/BF02976931. PMid:27518234.

Kim, T. P. N., Thi, N. V., Van, P. T., Diem, P. Q. N., Thuy, D. N. T., That, Q. T., \& Phi, P. N. K. (2013). Phytochemical constituents and determination of resveratrol from the roots of Arachis hypogea L. American Journal of Plant Sciences, 4(12), 2351-2358. http://dx.doi. org/10.4236/ajps.2013.412291.

Luna-Vázquez, F. J., Ibarra-Alvarado, C., Rojas-Molina, A., RomoMancillas, A., López-Vallejo, F. H., Solís-Gutiérrez, M., Rojas-Molina, J. I., \& Rivero-Cruz, F.. (2016). Role of nitric oxide and hydrogen sulfide in the vasodilator effect of ursolic acid and uvaol from black cherry Prunus serotina fruits. Molecules (Basel, Switzerland), 21(1), 78-94. http://dx.doi.org/10.3390/molecules21010078. PMid:26771591.
Macarthur, M., Hold, G. L., \& El-Omar, E. M. (2004). Inflammation and Cancer II. Role of chronic inflammation and cytokine gene polymorphisms in the pathogenesis of gastrointestinal malignancy. American Journal of Physiology. Gastrointestinal and Liver Physiology, 286(4), G515-G520. http://dx.doi.org/10.1152/ajpgi.00475.2003. PMid:15010360.

Mantovani, A., Allavena, P., Sica, A., \& Balkwill, F. (2008). Cancerrelated inflammation. Nature, 454(7203), 436-444. http://dx.doi. org/10.1038/nature07205. PMid:18650914.

Mongelli, E., Pampuro, S., Coussio, J., Salomon, H., \& Ciccia, G. (2000). Cytotoxic and DNA interaction activities of extracts from medicinal plants used in Argentina. Journal of Ethnopharmacology, 71(1-2), 145-151. http://dx.doi.org/10.1016/S0378-8741(99)001956. PMid:10904157.

Mosmann, T. (1983). Rapid colorimetric assay for cellular growth and survival: application to proliferation and cytotoxicity assays. Journal of Immunological Methods, 65(1-2), 55-63. http://dx.doi. org/10.1016/0022-1759(83)90303-4. PMid:6606682.

National Cancer Center. (2017). Annual report of cancer statistics in Korea in 2015. Korea: Ministry of Health and Welfare.

Newman, D. J., Cragg, G. M., \& Snader, K. M. (2003). Natural products as sources of new drugs over the period 1981-2002. Journal of Natural Products, 66(7), 1022-1037. http://dx.doi.org/10.1021/np0300961. PMid:12880330.

Salah, A., \& Bakibaev, A. (2017). Effective method of extraction of betulin diacetate from birch bark. Journal of Natural Products and Resources, 3(1), 90-93.

Saravi, S. S., Shokrzadeh, M., \& Shirazi, F. H. (2013). Cytotoxicity of Sambucus ebulus on cancer cell lines and protective effects of vitamins $\mathrm{C}$ and $\mathrm{E}$ against its cytotoxicity on normal cell lines. African Journal of Biotechnology, 12(21), 3360-3365.

Suffness, M. (1990). Assays related to cancer drug discovery. In K. Hostettmann (Ed.), Methods in plant biochemistry: assays for bioactivity (Vol. 6, pp. 71-133). Cambridge: Academic Press.

Tili, E., Michaille, J. J., Wernicke, D., Alder, H., Costinean, S., Volinia, S., \& Croce, C. M. (2011). Mutator activity induced by microRNA-155 (miR-155) links inflammation and cancer. Proceedings of the National Academy of Sciences of the United States of America, 108(12), 49084913. http://dx.doi.org/10.1073/pnas.1101795108. PMid:21383199.

Yesilada, E., Gürbüz, İ., \& Toker, G. (2014). Anti-ulcerogenic activity and isolation of the active principles from Sambucus ebulus L. leaves. Journal of Ethnopharmacology, 153(2), 478-483. http://dx.doi. org/10.1016/j.jep.2014.03.004. PMid:24632015.

Yeşilada, E., Üstün, O., Sezik, E., Takaishi, Y., Ono, Y., \& Honda, G. (1997). Inhibitory effects of Turkish folk remedies on inflammatory cytokines: interleukin- $1 \alpha$, interleukin- $1 \beta$ and tumor necrosis factor $\alpha$. Journal of Ethnopharmacology, 58(1), 59-73. http://dx.doi. org/10.1016/S0378-8741(97)00076-7. PMid:9324006.

Zur Hausen, H. (2007). Infections causing human cancer. Hoboken: John Wiley \& Sons CO. 